KINDERGARTEN: Journal of Islamic Early Childhood Education

p-ISSN: 2621-0339 |e-ISSN: 2621-0770, hal. 44- 58

Vol. 3, No. 1, April 2020

DOI: http://dx.doi.org/10.24014/kjiece.v3i1.9609

\title{
Persepsi Mahasiswa PIAUD terhadap Kuliah Online di Masa Pandemi Covid 19
}

\author{
La Ode Anhusadar \\ Program Studi Pendidikan Islam Anak Usia Dini, Fakultas Tarbiyah dan Ilmu Keguruan, LAIN Kendari \\ e-mail: sadar.wanchines@gmail.com
}

\begin{abstract}
ABSTRAK. Penelitian ini bertujuan untuk mengetahui persepsi mahasiswa tentang kuliah online, untuk mengetahui bentuk-bentuk aplikasi yang digunakan dalam kuliah online dan untuk mengetahui faktor-faktor penduk.ung dan fak.tor penghambat dalam kuliah online. Penelitian ini dilakukan dengan metode penelitian survey deskriptif, sampel pada penelitian ini adalah mahasiswa PIAUD semester 4 LAIN Kendari. Teknik pengumpulan data menggunakan wawancara dan angket. Temuan dalam penelitian ini adalah tempat yang biasa untuk kuliah dari 60 orang mahasiswa sebanyak 53 atau 88,3\% yang menjawab di rumah, sebanyak 2 orang Mahasiswa atau 3,3\% yang menjawab di kebun dan sebanyak 5 mahasiswa atau 8,3\% yang menjawab di rumah keluarga atau tetangga yang bagus jaringan internetnya. Mahasiswa menggunakan alat alektronik untuk mengikuti kuliah online adalah HP dan laptop. Aplikasi yang disuka dalam kuliah online, sebanyak 56 mahasiswa atau 91,8\% mahasiswa memilih aplikasi Whatsapp group, sebanyak 4 mahasiswa atau 6,5\% mahasiswa memilih aplikasi zoom dan sebanyak 1 mahasiswa atau 1,6\% mahasiswa memilih aplikasi email. Ketika ditanyakan kepada mahasiswa sejaubmana materi yang disampaikan melalui perkuliahan online dapat anda pahami oleh mahasiswa sebanyak 1 mahasiswa menjawab sangat dipahami, sebanyak 23 Mahasiswa menjawab dipahami, sebanyak 34 mahasiswa menjawab kadang-kadang dipahami dan sebanyak 4 mahasiswa menjadab tidak dipahami. Mahasiswa secara kesuluruban atau 100\% memilib kuliah tatap muka dibandingkan dengan kuliah online.
\end{abstract}

Kata Kunci : Persepsi, Kuliah Online, Pandemik Covid 19

\begin{abstract}
The purpose of this study to determine students' perceptions about online lectures process, to find out the forms of application used in online lectures and to find out the supporting factors and resistors factors in online lectures. This research was conducted by descriptive survey research methods, the 4th semester PLAUD students of IAIN Kendari as the sample of this study. The techique of data collection using interviews and questionnaires. This study find 53 or $88.3 \%$ from 60 students who answer at home, as many as 2 students or 3.3\% who answer in the garden and as many as 5 students or 8.3\% who answer family or neighbor's house with a good internet network. Students using electronic devices to attend online lectures are smartphones and laptops. Applications that are preferred in online lectures, as many as 56 students or 91.8\% of students use the Whatsapp group application, 4 students or $6.5 \%$ of students use the zoom application and 1 student or 1.6\% of students use the email application. When asked to students the extent to which the material delivered through online lectures can be understood by 1 student answers very well understood, 23 students answered understood, 34 students answered sometimes understood and as many as 4 students became non-understood. Students as a whole or $100 \%$ choose face-to-face lectures compared to online lectures.
\end{abstract}

Keyword : Perseption, Elearning, Pandemic Covid 19 


\section{PENDAHULUAN}

Dampak pandemi covid 19 pada tahun 2020 ini di Indonesia mulai merambah dunia pendidikan, pemerintah pusat hingga daerah memberikan kebijakan untuk meliburkan seluruh lembaga pendidikan. Hal ini dilakukan sebagai upaya mencegah meluasnya penularan virus corona. Diharapkan dengan seluruh lembaga pendidikan tidak melaksanakan aktivitas seperti biasanya, hal ini dapat meminimalisir menyebarnya penyakit covid 19 ini. Hal serupa juga sudah dilakukan oleh berbagai negara yang terpapar penyakit covid 19 ini, kebijakan lockdown atau karantina dilakukan sebagai upaya mengurangi interaksi banyak orang yang dapat memberi akses pada penyebaran virus corona. Penyebaran virus corona ini pada awalnya sangat berdampak pada dunia ekonomi yang mulai lesu, tetapi kini dampaknya dirasakan juga oleh dunia pendidikan. Kebijakan yang diambil oleh banyak negara termasuk Indonesia dengan meliburkan seluruh aktivitas pendidikan, membuat pemerintah dan lembaga terkait harus menghadirkan alternatif proses pendidikan bagi peserta didik maupun mahasiswa yang tidak bisa melaksanakan proses pendidikan pada lembaga pendidikan. Kebijakan di bidang pendidikan yang diambil oleh pemerintah terkait kasus COVID 19 yaitu : pembelajaran daring untuk anak sekolah, kuliah daring, ujian nasional 2020 ditiadakan, UTBK SBMPTN 2020 diundur, dan pelaksanaan SNMPTN masih dalam pengkajian (Sevima, 2020). Sebelum menjadi pandemik, virus ini mulanya terjadi di Kota Wuhan, Provinsi Hubei, Cina pada bulan Desember 2019. Terdapat sebuah laporan yang memberitakan bahwa sedang terjadi wabah pneumonia terkait dengan virus yang disebut sebagai Severe Acute Respiratory Syndrome Coronavirus-2 (SARS-CoV-2). Infeksi dari virus tersebut menjalar dengan cepat hingga ke seluruh daerah di China dan negara-negara lainnya di seluruh dunia pada beberapa minggu berikutnya. (Hermansyah, 2020). Menurut WHO Coronaviruses $(\mathrm{CoV})$ merupakan bagian dari keluarga virus yang menyebabkan penyakit mulai dari flu hingga penyakit yang lebih berat seperti Middle East Respiratory Syndrome (MERS-CoV) and Severe Acute Respiratory Syndrome (SARS-CoV). Penyakit yang disebabkan virus corona, atau dikenal dengan COVID-19, adalah jenis baru yang ditemukan pada tahun 2019 dan belum pernah diidentifikasi menyerang manusia sebelumnya (Nailul Mona, 2020).

Penyesuaian kebijakan pendidikan di masa pandemik corona ini pun mempengaruhi kebijakan pada perguruan tinggi keagamaan. Ini dapat terlihat pada Surat Edaran Nomor: 657/03/2020 Tentang Upaya Pencegahan Penyebaran Covid-19 (Corona) di lingkungan Perguruan Tinggi Keagamaan Islam yang berbunyi pimpinan PTKI melakukan pengalihan, Perkuliahan tatap muka menjadi pembelajaran jarak jauh mulai 16-29 Maret 2020 dan untuk selanjutnya akan dilakukan evaluasi. Melihat kondisi pandemic corona di Indonesia belum memperlihatkan penurunan angka pasien positif, kemudian Surat Edaran Nomor 697/03/2020 Tentang Perubahan Atas Surat Edaran Direktur Jenderal Pendidikan Islam Nomor 657/03/2020 Tentang Upaya Pencegahan Penyebaran Covid-19 (Corona) Di lingkungan Perguruan Tinggi Keagamaan Islam yang berbunyi proses perkuliahan hingga akhir semester genap tahun akademik 2019/2020 pada setiap perguruan tinggi keagamaan Islam baik negeri maupun swasta sepenuhnya di lakukan dalam jaringan (online) (Kemenag, 2020).

Menindaklanjuti surat edaran tersebut, Rektor IAIN Kendari mengeluarkan surat edaran terkait dengan proses perkuliahan di masa pandemic covid 19. Edaran Rektor tentang : Tindak Lanjut Kebijakan Pencegahan Penyebaran Covid-19 Pada Area Publik di Lingkungan Institut Agama Islam Negeri Kendari Nomor : 0131/In.23/03/2020 yang berbunyi Kegiatan akademik 
dilaksanakan secara online sebagai perwujudan dari semangat kampus merdeka dengan mengacu pada Protokol Akademik yang dikeluarkan Rektor IAIN Kendari sebagai berikut:

1. Perkuliahan berlangsung dengan menggunakan Sistem Perkuliahan Online (SPO)

2. SPO dilakukan dengan memanfaatkan aplikasi Zoom, Google Classroom, E-Learning, Facebook, Whats App, Hangout, dll dengan menghindari adanya kontak fisik langsung antara dosen dan mahasiswa atau antara mahasiswa dan mahasiswa

3. SPO dapat dilakukan dengan cara memberikan tugas mandiri atau terstruktur kepada mahasiswa yang diinformasikan secara online.

4. Tugas individu dapat berupa pembuatan makalah, power point, desain, hafalan, atau membuat jawaban atas beberapa pertanyaan yang diajukan dosen tentang bahasan mata kuliah, dan bila memungkinkan dikaitkan dengan Covid-19 yang dapat dikaji dalam berbagai perspektif

5. Metode pembelajaran dilakukan melalui seminar, diskusi, dan tanya jawab atau metode lainnya secara online

6. Tugas yang diberikan hendaknya ditentukan batas waktu penyelesaiannya, sehingga dapat dilanjutkan dengan tugas-tugas berikutnya dengan memakai prinsip simpel, efektif dan efisien serta tidak terlalu membebani mahasiswa

7. Absensi mahasiswa dalam pembelajaran SPO dilakukan dengan melihat kehadiran mahasiswa melalui aplikasi; atau dengan cara melihat tugas-tugas yang dikumpulkan secara online atau dengan memberikan affirmasi sebagai bentuk pertimbangan lain menyikapi situasi yang terjadi

8. Sekali penugasan terhadap mahasiswa dapat diekuivalensikan dengan beberapa kali pertemuan, tergantung pada beban materi yang diberikan

9. Evaluasi terhadap proses perkuliahan yang menggunakan SPO dapat dilakukan dengan menilai keaktifan dalam diskusi, argumentasi yang dibangun mahasiswa, alur pikir dalam makalah, bobot pesan yang disampaikan dalam power point, dll.

10. Mata kuliah yang belum memiliki Whatsapp group, segera langsung menyampaikan kepada Ketua Tingkatnya untuk membuat Whatsapp group sebagai media berkomunikasi (IAIN Kendari, 2020).

Perkembangan teknologi informasi dan komunikasi telah memberikan pengaruh dalam dunia pendidikan di Indonesia khususnya dalam proses pembelajaran. Salah satu indikasi dari fenomena ini adalah adanya pergeseran dalam proses pembelajaran dimana interaksi antara pendidik dan peserta didik tidak hanya dilakukan melalui hubungan tatap muka tetapi juga dilakukan dengan media-media komunikasi seperti komputer, internet, dan sebagainya. Menurut Ade Kusuma kuliah online merupakan proses pembelajaran yang memanfaatkan teknologi informasi, dalam hal ini memanfaatkan internet sebagai metode penyampaian, interaksi dan fasilitasi. Didalamnya terdapat dukungan layanan belajar yang dapat dimanfaatkan oleh peserta belajar. Selain itu juga tersedia rancangan sistem pembelajaran yang dapat dipelajari dan diketahui oleh tiap peserta belajar (Saputro, Somantri, \& Nugroho, 2017). Menurut Akkoyunlu dan Soylu model pembelajaran online juga bisa juga model Blended Learning merupakan sebuah pendekatan pembelajaran yang memadukan kelebihan pada pembelajaran tatap muka dan e-learning. Dalam pembelajaran tatap muka, peserta didik bisa bertemu langsung dengan pendidik. Oleh karena itu, interaksi sosial bisa tetap terjadi di dalam kelas dimana peserta didik memang masih perlu panduan dalam pembelajaran. Peserta didik bisa berinteraksi dengan pendidik maupun teman mereka sehingga peserta didik akan secara langsung memperoleh feedback dari hasil pembelajaran. 
Sementara itu, pembelajaran online menawarkan pembelajaran sepanjang waktu dimana pembelajaran bisa diakses kapan saja dan dimana saja (Sofiana, 2015).

Menurut Nichols mendefinisikan e-learning sebagai "pedagogy empowered by digital technology" artinya e-learning dapat diartikan secara singkat sebagai pendidikan yang didukung penuh oleh teknologi digital. Dengan kata lain, e-learning merupakan proses pembelajaran yang memanfaatkan dukungan teknologi digital. Teknologi disini tidak terbatas pada teknologi internet, namun juga termasuk dalam teknologi seperti CD-ROM dan DVD- ROM (Solichin, 2009). Pembelajaran online adalah pembelajaran yang memanfaatkan keunggulan komputer sebagai media perantara pengajar dan mahasiswa agar mudah berkomunikasi. Pembelajaran online memberikan kesempatan kepada mahasiswa untuk mengajukan pertanyaan atau mengemukakan pendapat secara tidak langsung. Pembelajaran online memanfaatkan bahan ajar yang bersifat mandiri yang dapat diakses siapa saja dan kapan saja melalui teknologi internet. Pembelajaran online akan memudahkan penyempurnaan dan penyimpanan materi perkuliahan sehingga pemutakhiran bahan ajar elektronik mudah dilakukan. Menurut Heinich dkk mengemukakan sejumlah kelebihan penggunaan media komputer dalam pembelajaran. Pembelajaran dengan komputer (termasuk di dalamnya pembelajaran online) memungkinkan siswa dapat melakukan kegiatan belajar secara mandiri, tanpa terikat oleh waktu dan tempat karena dapat diakses melalui internet. Program pembelajaran menggunakan komputer juga dapat menumbuhkan sikap positif siswa terhadap materi dan proses belajar. Program pembelajaran dengan komputer dapat mengajarkan konsepkonsep aturan, prinsip, langkah-langkah, proses, dan kalkulasi yang kompleks (Indiati, 2008).

Menurut Romiszowski menyampaikan bahwa saat ini terdapat ratusan perguruan tinggi maya yang menyebar di seluruh dunia. Data tersebut menunjukkan bahwa peminat pembelajaran online learning terus meningkat dari tahun ke tahun. Pada tahun 2003, jumlah pebelajar online telah mencapai 6.976 orang dari 67 negara seperti Singapura, Malaysia, Hongkong, Afrika Selatan, UAE, India, Jerman, dan Kanada. Kemudian meningkat menjadi 7.707 orang pada 2007 termasuk pebelajar online dari Indonesia. Data ini juga terdiri dari 100.000 mahasiswa yang terdaftar. perguruan tinggi seperti ini dirancang dalam rangka memberikan kursus belajar dalam jumlah besar, menggunakan teknik pembelajaran jarak jauh dan juga membuat program pembelajaran dengan biaya efektif. Sekitar 15 perguruan tinggi (Universitas) telah masuk dalam kategori mega universitas, namun baru tujuh universitas yang masuk dalam kategori Super Mega Universitas, salah satunya adalah Universitas Terbuka (UT) Indonesia (Yuberti, 2015)

Model pembelajaran online juga dikembangkan oleh kampus Universitas Terbuka. Menurut Budiwati, tutorial yang disediakan oleh UT bertujuan untuk mengakomodasi interaksi mahasiswa dengan materi bahan ajar, interaksi mahasiswa dengan tutor melalui berbagai modus tutorial, dan interaksi antar mahasiswa melalui beragam kegiatan kelompok belajar. Melalui proses belajar mandiri, belajar terbimbing, dan pemanfaatan berbagai sumber belajar sebagai satu kesatuan utuh dalam sistem pembelajaran, diharapkan mahasiswa dapat melakukan proses belajar yang optimum dengan hasil yang memuaskan (Yuliana \& Winata, 2009). Universitas Terbuka pun mengembangan model pembelajaran dengan menggunakan facebook. Sebagai sebuah sistem, Facebook merupakan sebuah sistem yang sangat handal, mempunyai tata visual yang menarik, mudah dipergunakan, dan banyak yang menggunakannya. Sebagai sebuah aplikasi, Facebook mempunyai fitur-fitur yang dapat dipergunakan untuk menunjang KBM jarak jauh. Fitur-fitur tersebut mencakup .

1. Fitur untuk menyampaikan materi dalam berbagai format (text, link, file, rekaman video), 
2. Fitur untuk berinteraksi secara asynchronous (message, status \& Comment,) dan juga synchronous (chatting) antara tutor dengan peserta atau antar peserta.

3. Fitur untuk memberi notifikasi yang terhubung dengan peralatan telephon seluler (mobile devise) dan email tutor dan peserta

4. Ditinjau dari syarat-syarat sebuah sistem KBM jarak jauh, juga mempunyai kendala dan keterbatasan sebagai berikut :

a. Sistem merupakan sebuah sistem media sosial di awan yang dimiliki oleh sebuah perusahaan bisnis independen. Sehingga tidak memungkinkan untuk mengkustomisasi ataupun mendapatkan layanan dukungan khusus untuk penggunaan sebagai sistem KBM jarak jauh. Keberlangsungan sistem juga tergantung kepada kebijakan pemilik sistem.

b. Materi tutorial yang mengandung simbol dan rumus-rumus keilmuwan tidak dapat dibuat dan ditampilkan dengan benar sehingga sulit dipahami.

c. Tidak dapat dipergunakan untuk memberikan penilaian hasil evaluasi secara formal (yang berkaitan dengan administrasi KBM) (Patria \& Yulianto, 2011)

IKIP Mataram mengembangkan model pembelajaran online dengan mengggunakan aplikasi Moodle. Moodle adalah sebuah Open Source Course Management System (CMC), yang berarti tempat belajar dinamis dengan menggunakan model berorientasi objek, juga dikenal sebagai Learning Management System (LMS) atau Virtual Learning Environment (VLE). Moodle merupakan sebuah program aplikasi yang dapat merubah media pembelajaran ke dalam bentuk web. Manfaat dari pengunaan LMS menggunakan Moodle secara online sangat penting, diantaranya adalah mengatasi keterbatasan frekuensi tatap muka antara mahasiswa dengan dosen (Herayanti, Fuaddunnazmi, \& Habibi, 2017).

Upaya Peningkatan Kualitas pendidikan dengan penggunaan system kuliah online, sudah dilakukan Universitas Komputer Indonesia (UNIKOM), Sistem tersebut diberi nama UNIKOM Kuliah Online, yaitu suatu Perangkat Lunak Bantu belajar berbasis Web yang dapat digunakan untuk memudahkan menyebar- kan materi belajar melalui Internet yang dikembangkan oleh Team Unikom Center. pembuatan UNIKOM Kuliah Online bertujuan untuk :

1. Memudahkan siswa untuk mendapatkan materi bahan ajar

2. Meningkatkan partisipasi aktif dari mahasiswa

3. Meningkatkan kemampuan belajar mandiri mahasiswa

4. Meningkatkan kualitas materi pendidikan dan pelatihan,

5. Meningkatkan kemampuan menampilkan informasi dengan perangkat teknologi informasi

6. Memperluas daya jangkau proses belajar mengajar dengan menggunakan jaringan komputer tidak terbatas pada ruang dan waktu (Edi Firdaus, 2014)

Mahasiswa PIAUD yang nanti akan menjadi pendidik PAUD nanti harus mengusai dan mengembangkan ilmu pengetahuan dan teknologi. Menurut cristianti bahwa Pendidik anak usia dini harus memiliki keahlian dalam melakukan refleksi dan menganalisis kegiatan mengajarnya. Karakteristik ini perlu dikembangkan untuk meningkatkan kemampuan guru dalam mengembangkan rencana lanjutan. Hasil analisis dan refleksi tersebut kemudian harus disampaikan pada orang lain dalam bentuk telaah yang diambil dari analisis terhadap kekuatan dan kelemahan rencana dan pelaksanaan pembelajaran yang telah dilakukan. Pendidik berusaha untuk memperbaiki perencanaan dan pelaksanaan pembelajaran agar menghasilkan kualitas pembelajaran yang lebih baik (La Ode Anhusadar; Islamiyah, 2019). Begitu banyak aplikasi yang bisa digunakan untuk membantu proses pembelajaran online, Nextren telah merangkum 3 aplikasi yang bisa kamu gunakan untuk tetap bisa berkuliah dari rumah: 


\section{Zoom Cloud Meeting}

2. Skeype

3. Whats App (NEXTREN, 2020).

Pengguanaan aplikasi online dalam pembelajaran tentu banyak manfaat yang bisa diperoleh. Penggunaan aplikasi online ini pun dapat digunakan oleh prodi dalam kegiatan pengumpulan data mahasiswa, dosen, dan lain-lainnya. Hasil penelitian yang dilakukan oleh Bayu Febriadi dan Nurliana Nasution terkait dengan online menyimpulkan bahwa kegiatan penelitian pengumpulan RPKPS online dapat membantu dosen dan program studi dalam pengolahan data untuk peningkatan ketepatan komptensi program studi yang diberikan sebesar 4,8 point, dimana sebelum dilakukan kegiatan pengetahuan karyawan dalam pengolahan data kuisioner dengan ratarata 4,27 menjadi 4,75. 2. Program studi sangat terbantu dengan adanya pengumpulan RPKPS online yaitu pada bagian pengontrolan RPKPS yang lebih tinggi dengan nilai rata-rata 4,5 point, sedangkan yang paling rendah padas layanan pengambilan dengan nilai rata-rata 2,3 point (Febriadi \& Nasution, 2017).

\section{METODE}

Penelitian ini dilakukan dengan metode penelitian survey deskriptif, metode ini hampir sama dengan metode deskriptif. Perbedaannya, metode survei penjelas, menekankan pada pencarian hubungan sebab akibat atau kausal antara variabel yang diteliti. Metode survey merupakan penelitian yang sumber data dan informasi utamanya diperoleh dari responden sebagai sampel penelitian dengan menggunakan kuesioner atau angket sebagai instrumen pengumpulan data. Sampel pada penelitian ini adalah mahasiswa PIAUD semester 4 IAIN Kendari. Teknik pengumpulan data menggunakan wawancara dan angket. Analisis data dalam penelitian ini ialah mengatur, mengurutkan, mengelompokkan, memberikan kode, dan mengategorikannya. Adanya kegiatan mengelompokkan, membuat suatu urutan, memanipulasi serta menyingkatkan data adalah supaya data mudah untuk dibaca. Analisis yang digunakan sudah jelas yaitu diarahkan untuk menguji hipotesis yang telah dirumuskan. Hipotesis dalam survey ini adalah persepsi mahasiswa PIAUD terhadap kuliah online di masa pandemi covid 19 masih dalam kategori baik.

\section{HASIL DAN PEMBAHASAN}

Mahasiswa PIAUD IAIN Kendari merupakan mahasiswa yang berasal dari 17 Kabupaten Kota yang ada di Provinsi Sulawesi Tenggara dan ada juga yang berasal dari luar Provinsi Sulawesi Tenggara. Sehingga dalam mendapatkan akses jaringan internet pun berbeda-beda tiap mahasiswa. Ini dapat digambarkan pada tabel berikut:

Tabel 1. Tempat Biasa Mahasiswa Kuliah Online.

\begin{tabular}{|l|l|c|c|}
\hline No & Mahasiswa & Persen (\%) & Jawaban \\
\hline 1 & 53 & 88,3 & Rumah \\
\hline 2 & 2 & 3,3 & Kebun \\
\hline 3 & 5 & 83 & $\begin{array}{c}\text { Rumah keluarga atau tetangga yang bagus jaringan } \\
\text { internetnya }\end{array}$ \\
\hline
\end{tabular}

Pada tabel di atas terlihat bahwa mahasiswa ketika ditanyakan dimana tempat biasa untuk kuliah online. Dari 60 orang mahasiswa sebanyak 53 atau 88,3 \% yang menjawab di rumah, sebanyak 2 orang Mahasiswa atau 3,3\% yang menjawab di kebun dan sebanyak 5 mahasiswa atau $8,3 \%$ yang menjawab di rumah keluarga atau tetangga yang bagus jaringan internetnya. Dari 
gambaran tersebut ternyata mahasiswa masih mengalami kesulitan dalam mengikuti kuliah online yang disebabkan oleh kondisi tempat tinggal mereka yang belum mendapatkan jaringan internet, sehingga masih ada mahasiswa yang harus kuliah di kebun dan bahkan harus mencari rumah keluarga untuk dapat kuliah online. Sesuai data BPS Provinsi Sulawesi Tenggara masih banyak daerah yang tidak dapat jaringan internet seperti tabel berikut: (BPS Provinsi Sultra, 2019).

\begin{tabular}{|c|c|c|c|c|c|c|c|c|c|c|c|}
\hline \multicolumn{12}{|c|}{$\begin{array}{c}\text { Tabel } 2 \\
\text { Banyaknya Desa/Kelurahan Menurut Keberadaan Base Transceiver Station (BTS), } \\
\text { Sinyal Telepon Seluler, Dan Sinyal Internet GSM Atau CDMA, } 2018\end{array}$} \\
\hline \multirow[b]{2}{*}{$\underset{\text { Ka }}{\text { Kabupaten/Ko }}$} & \multicolumn{2}{|c|}{$\begin{array}{l}\text { Keberadaan } \\
\text { BTS }\end{array}$} & \multicolumn{4}{|c|}{ Kekuatan Sinyal Telepon Seluler } & \multicolumn{4}{|c|}{ Sinyal Internet GSM Atau CDMA } & \\
\hline & Ada & $\begin{array}{l}\text { Tida } \\
\text { k Ada }\end{array}$ & $\begin{array}{l}\text { Sangat } \\
\text { Kuat }\end{array}$ & $\begin{array}{c}\mathrm{Ku} \\
\text { at }\end{array}$ & Lemah & $\begin{array}{l}\text { Tidak } \\
\text { Ada } \\
\text { Sinyal }\end{array}$ & $\begin{array}{c}\text { 4G/LT } \\
\quad \mathrm{E}\end{array}$ & $\begin{array}{c}3 \mathrm{G} / \mathrm{H} / \mathrm{H} \\
+\end{array}$ & $\begin{array}{c}2 \mathrm{G} / \mathrm{E} / \mathrm{GPR} \\
\mathrm{S}\end{array}$ & $\begin{array}{l}\text { Tidak } \\
\text { Ada } \\
\text { Sinyal } \\
\text { Interne } \\
\quad t\end{array}$ & \\
\hline Buton & 27 & 68 & 22 & 34 & 28 & 11 & 10 & 31 & 33 & 10 & \\
\hline Muna & 41 & 145 & 39 & 98 & 45 & 4 & 39 & 113 & 12 & 18 & \\
\hline Konawe & 49 & 322 & 64 & $\begin{array}{c}20 \\
8 \\
\end{array}$ & 69 & 30 & $8^{12}$ & 177 & 24 & 12 & \\
\hline Kolaka & 39 & 96 & 33 & 79 & 21 & 2 & 55 & 61 & 8 & 9 & \\
\hline Konawe Selatan & 64 & 293 & 47 & $\begin{array}{c}16 \\
6 \\
\end{array}$ & 134 & 10 & 84 & 222 & 23 & 18 & \\
\hline Bombana & 32 & 111 & 23 & 46 & 53 & 21 & 36 & 41 & 18 & 27 & \\
\hline Wakatobi & 24 & 76 & 10 & 69 & 20 & 1 & 33 & 47 & 12 & 7 & \\
\hline Kolaka Utara & 29 & 104 & 10 & 72 & 46 & 5 & 24 & 84 & 15 & 5 & \\
\hline Buton Utara & 8 & 83 & 12 & 30 & 45 & 4 & 24 & 44 & 4 & 15 & \\
\hline Konawe Utara & 9 & 164 & 12 & 63 & 73 & 25 & 29 & 65 & 6 & 48 & \\
\hline Kolaka Timur & 18 & 115 & 20 & 46 & 42 & 25 & 38 & 44 & 15 & 11 & \\
\hline $\begin{array}{l}\text { Konawe } \\
\text { Kepulauan }\end{array}$ & 13 & 83 & 10 & 19 & 44 & 23 & 13 & 8 & 8 & 44 & \\
\hline Muna Barat & 15 & 71 & 12 & 35 & 39 & - & 17 & 32 & 31 & 6 & \\
\hline Buton Tengah & 23 & 54 & 9 & 29 & 38 & 1 & 14 & 39 & 23 & - & \\
\hline Buton Selatan & 14 & 56 & 27 & 23 & 19 & 1 & 33 & 29 & 1 & 6 & \\
\hline Kota Kendari & 49 & 16 & 40 & 22 & 3 & - & 48 & 14 & 1 & 2 & \\
\hline Kota Baubau & 24 & 19 & 8 & 29 & 6 & - & 26 & 17 & - & - & \\
\hline $\begin{array}{l}\text { SULAWESI } \\
\text { TENGGARA }\end{array}$ & 478 & 1876 & 398 & $\begin{array}{l}10 \\
68\end{array}$ & 725 & 163 & $1^{65}$ & 1068 & 234 & $8^{23}$ & \\
\hline
\end{tabular}

Kondisi jaringan internet yang kurang mendukung tidak membuat mahasiswa patah semangat untuk tidak ikut perkuliahan, sesuai pendapat dari 2 mahasiswa yang harus kuliah online di kebun bahwa, kami tetap semangat mengikuti kuliah online setiap hari dan menyelesaikan tugas yang diberikan oleh dosen. (Wawancara Sintania Anggraeni \& Ayu saputri, 13 April 2020).
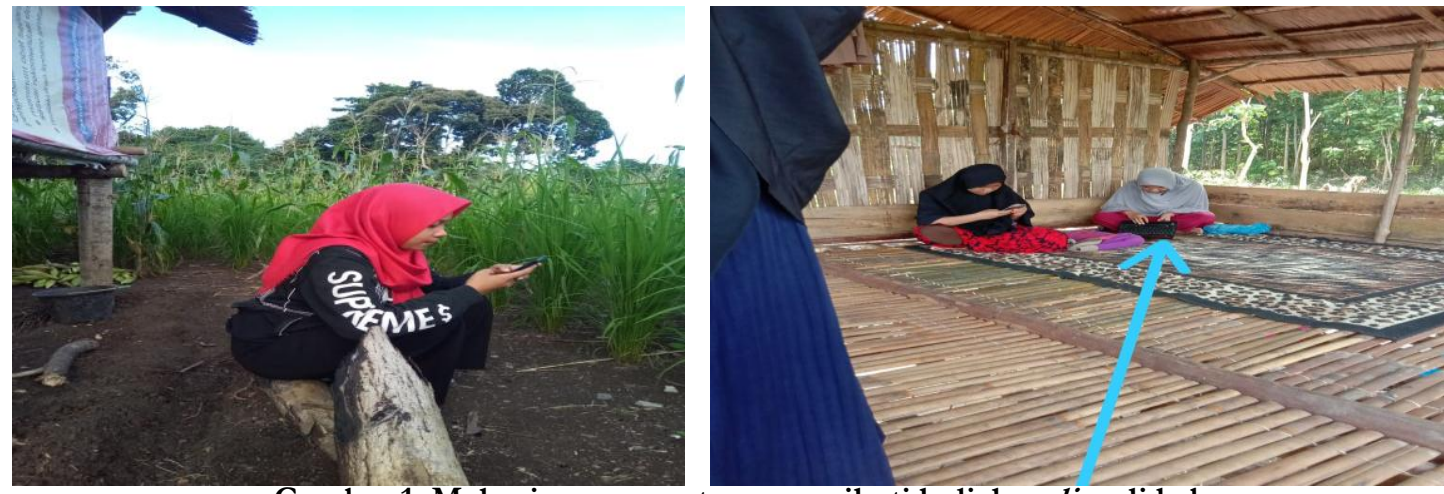

Gambar 1. Mahasiswa sementara mengikuti kuliah online di kebun 
Jika dilihat dari penggunaan alat elektronik yang digunakan oleh mahasiswa dalam mengikuti kuliah online dapat dilihat pada grafik di bawah ini:

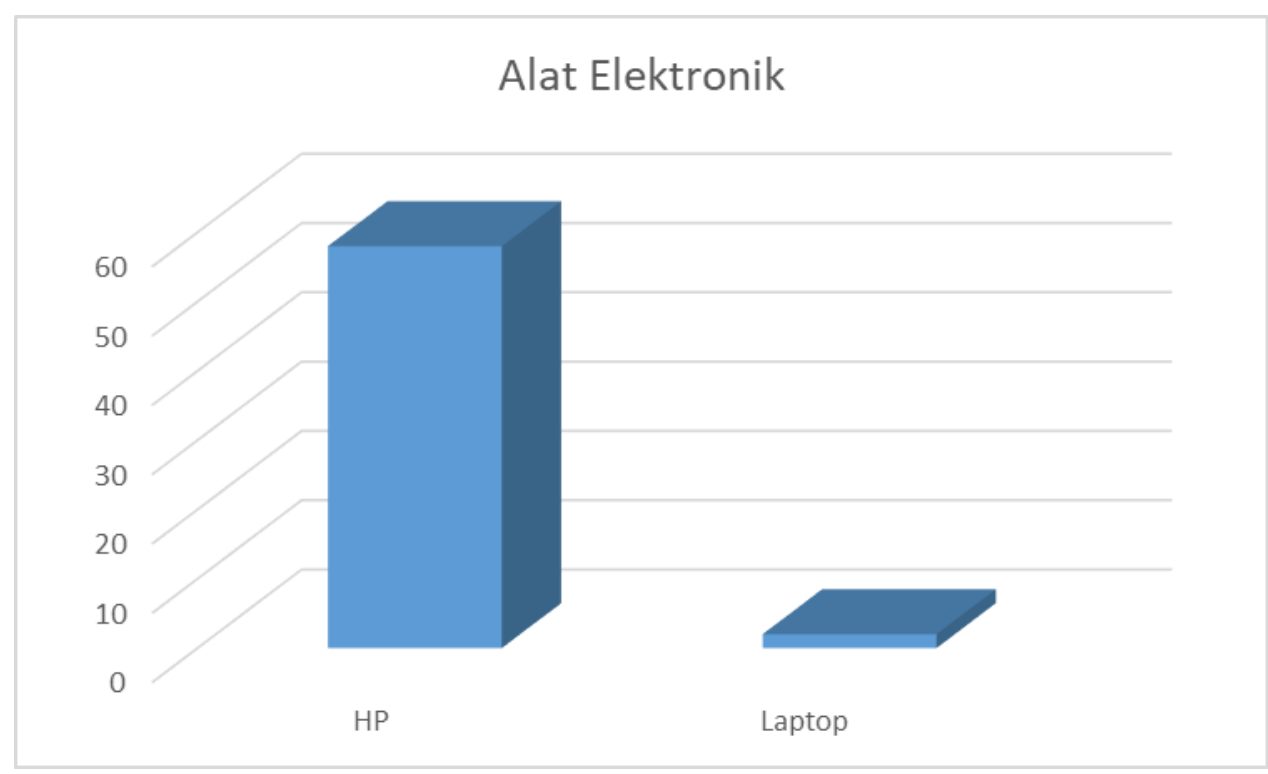

Gambar 2. Alat elektronik untu kuliah online

Dari grafik di atas dapat terlihat bahwa alat elektronik yang digunakan oleh mahasiswa untuk mengikuti kuliah online adalah HP dan laptop, dimana sebanyak 58 atau 96,6\% mahasiswa menggunakan HP dalam mengikuti kuliah online dan sebanyak 2 atau 3,4\% mahasiswa menggunakan laptop dalam mengikuti kuliah online. Persepsi mahasiswa tentang kuliah online ini beraneka ragam seperti yang diungkapkan oleh Wa Ode Meilin Saputri bahwa kuliah online yang dilakukan dengan memanfaatkan media komunikasi, seperti HP atau laptop yang berbasis online (menggunakan jaringan internet), sementara Iglima Aderista Kuliah Online atau sistem perkuliahan berbasis daring, kuliah online disebut juga e-learning atau online course adalah proses perkuliahan dengan menggunakan teknologi informasi dan komunikasi, dalam hal ini internet, sementara Wulan mengungkapkan bahwa kuliah online adalah kuliah yang mewajibkan paket internet bagi setiap mahasiswa, menurut Zulfira Zilondae bahwa kuliah online merupakan sistem perkuliahan yang memanfaatkan akses internet sebagai media pembelajaran. Tetapi pembelajaran berbasis internet mempunyai dampak positif dan negatif, ada pula yang menganggap bahwa kuliah online itu susah seperti yang diungkapkan oleh Candrawati bahwa kuliah online ribet gara-gara tidak ada jaringan internet. (Wawancara, 13 April 2020).

E-learning sebenarnya mempunyai definisi yang sangat luas, bahkan suatu portal yang menyediakan informasi mengenai topik tertentu dapat tercakup dalam lingkup e-learning. Namun, istilah e-learning lebih tepat ditujukan sebagai usaha untuk membuat sebuah transformasi proses belajar mengajar yang ada di sekolah atau kampus ke dalam bentuk digital yang memanfaatkan fasilitas dari teknologi informasi yaitu internet. (Muzid \& Munir, 2005). Online learning sampai saat ini masih dianggap sebagai terobosan atau paradigma baru dalam kegiatan belajar mengajar dimana dalam proses kegiatan belajar mengajar karena antara mahasiwa dan dosen tidak perlu hadir ruang kelas. Mereka hanya mengandalkan koneksi internet untuk melakukan proses kegiatan belajar dan proses tersebut dapat dilakukan dari tempat yang berjauhan. Karena kemudahan dan kepraktisan sistem perkuliahan virtual atau online learning, tidak heran bila banyak institusi yang menggunakan perkuliahan online. Dengan demikian pembelajaran online dapat dilakukan dari manapun mahasiswa dan dosen berada. Namun pertanyaannya adalah apakah 
aktivitas dan psikologi belajar dalam pembelajaran online memiliki nuansa yang sama atau sekurangnya mendekati dengan aktivitas dan psikologi belajar dalam pembelajaran tatap muka.

Proses perkuliahan tatap muka di kelas yang dilakukan membutuhkan persiapan untuk mengikuti perkuliahan seperti menyiapkan materi, makalah, buku bacaan, buku tulis dan lain-lain. Begitu pula kuliah online membutuhkan persiapan yang dilakukan oleh mahasiswa sebelum mengikuti perkuliahan online. Berbagai ragam tanggapan mahasiswa terkait dengan persiapan yang dilakukan sebelum kuliah online seperti yang di ungkapkan oleh Siti Yuliani bahwa yang disiapkan adalah kuota atau paket data, jika tidak ada paket maka kuliah tidak bisa dilakukan dan juga stamina yang baik karena terkadang dosen juga memberikan tugas, Noni Rahmawati mengungkapkan bahwa materi yang akan kita pelajari ketika kuliah online akan dimulai dan tentunya menyiapkan hp atau laptop dan kuota untuk kuliah. Pendapat lain oleh Hatima Mardin bahwa yang harus disiapkan yaitu Handphone, pulsa, buku tulis, pulpen, penghapus, pensil, Nurul Magfiroh mengungkapkan bahwa yang perlu dipersiapkan adalah Paket data/ kesediaan data internet dan kesiapan jasmani dan rohani. (Wawancara, 13 April 2020). Dalam proses perkuliahan online tentu ada aplikasi yang harus digunakan untuk membantu proses perkuliahan online. Aplikasi yang digunakan dosen dalam perkuliahan online pada mahasiswa PIAUD IAIN Kendari semester IV adalah aplikasi Whatsapp group, Zoom dan Email. (Wawancara, 13 April 2020). Dari hasil angket yang dijawab oleh mahasiswa aplikasi kulian online yang mahasiswa suka dapat dilihat dari diagram berikut:

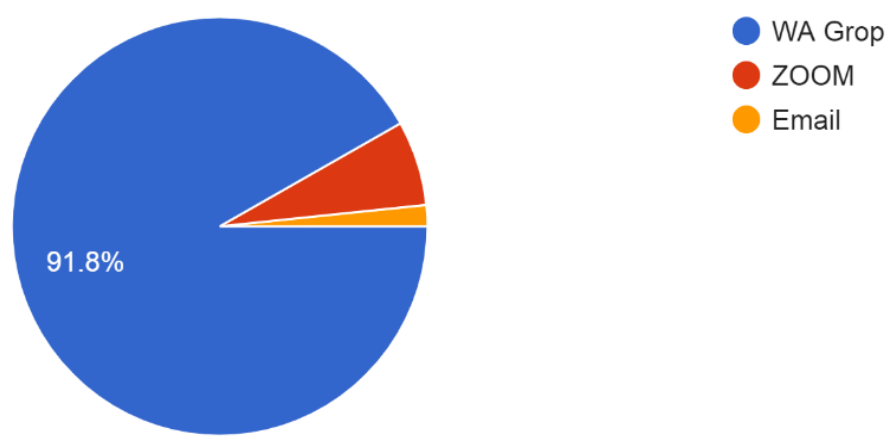

Gambar 3. Aplikasi yang disuka mahasiswa

Dari diagram di atas terlihat bahwa sebanyak 56 mahasiswa atau 91,8\% mahasiswa memilih aplikasi Whatsapp group, sebanyak 4 mahasiswa atau 6,5\% mahasiswa memilih aplikasi Zoom dan sebanyak 1 mahasiswa atau 1,6\% mahasiswa memilih aplikasi email. Respon mahasiswa yang memilih aplikasi Whatsapp group seperti hasil wawancara berikut ini, menurut Tri Nur Fazirah bahwa karena di Whatsapp lebih mudah karena jaringan mendukung. Kalau di zoom kadang tidak bisa connect, Sulistia Hardinata mengungkapkan bahwa menggunakan wa meskipun jaringan jelek, saya msih bisa ikut kuliah, Tri Amalia mengungkapkan bahwa kenapa saya menyukai kuliah online menggunakan WhatsApp ,karna tidak ribet, tidak sama seperti aplikasi lain harus jaringannya bagus, sedangkan di kampung saya jaringannya kurang bagus, jadi itu yang buat saya menyukai kuliah online menggunakan aplikasi Whats $A p$, Suni Sundarari mengungkapkan bahwa Karena jika menggunakan Media Whatsapp group, lebih hemat paket data dan tidak terlalu susah jika jaringan sedang tidak mendukung. (wawancara, 13 April 2020). Hasil penelitian yang dilakukan oleh Andika Prajana menyimpulkan bahwa Teknologi Server dan jaringan saat ini berkembang sangat pesat, salah satunya adalah Whats App. Model 
teknologi yang digunakan dalam jaringan Server-Client (WhatsApp) beragam diantaranya, halaman web dengan HTML Statis, Teknologi CGI Script, Teknologi Serverside Script (ASP, PHP, JSP). Aplikasi jejaring sosial yang sekarang berkembang salah satunya seperti WhatsApp dapat dimanfaatkan sebagai e-learning yang merupakan salah satu karakteristik dari generasi teknologi web 2.0, colaborating and sharing. Dengan memanfaatkan beberapa aplikasi yang ada di Facebook, interaktivitas system kepada pengguna dapat ditingkatkan. Tidak semua aplikasi WhatsApp dapat diintegrasikan ke dalam sistem (WhatsApp), kebanyakan aplikasi yang berhasil diintegrasikan adalah aplikasi yang telah disertifikasi oleh facebook. (Andika Prajana, 2017).

Dari hasil angket yang dijawab oleh mahasiswa aplikasi kulian online yang mahasiswa tidak suka dapat dilihat dari diagram berikut:

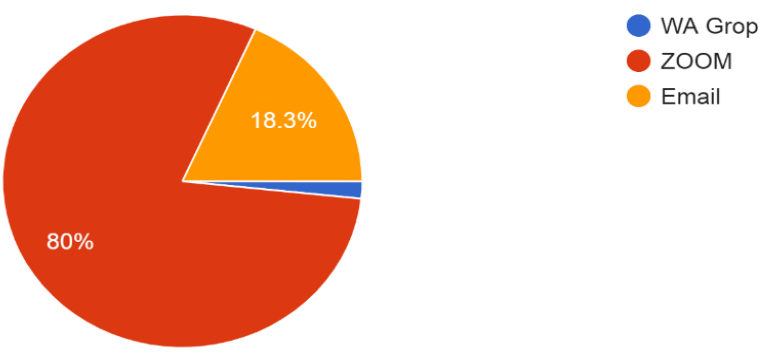

Gambar 4. Aplikasi yang tidak disuka mahasiswa

Dari diagram di atas terlihat bahwa sebanyak 48 mahasiswa atau $80 \%$ mahasiswa memilih aplikasi zoom, sebanyak 11 mahasiswa atau 18,3\% mahasiswa memilih aplikasi email dan sebanyak 1 mahasiswa atau 1,7\% mahasiswa memilih aplikasi email Aplikasi Whatsapp grup. Respon mahasiswa yang memilih aplikasi Whatsapp Group seperti hasil wawancara berikut ini, menurut Nuzul Fadhilah bahwa aplikasi zoom jaringannya yang tidak memadai sehingga dalam proses pembelajaran kurang efektif dan efisien karena terkadang terdengar suaranya dan kadang tidak sehingga mahasiswa tidak paham apa yang disampaikan oleh dosen yang bersangkutan, menurut Safitry Yani bahwa penggunaan aplikasi zoom dalam melakukan join ke dosen, kurang jelas dalam penjelasan yang dilakukan oleh dosen seperti suara yang kurang jelas suaranya mungkin diakibatkan oleh jaringan yg kurang, menurut Farlin Nadila bahwa aplikasi Zoom ribet penggunaannya dan memakan banyak paket internet, terkadang juga perkuliahan terkendala karena jaringan, menurut Nurul Magfiroh aplikasi zoom memerlukan paket data yang banyak, menguras paket dalam waktu kurang lebih 30 keatas (Wawancara, 13 April 2020). Zoom merupakan salah satu aplikasi yang digunakan dalam melakukan kuliah online. Penggunaan aplikasi zoom di masa pandemic covid 19 ini meningkat, Antara 22 Februari dan 22 Maret 2020, unduhan aplikasi Zoom meningkat sebesar 1.270 persen, lebih dari 12 kali lipat, menurut data yang dikumpulkan oleh Learnbonds. Unduhan tertinggi ada di platform dengan sistem operasi IOS dan Android. (tekno.tempo.co, 2020). Namun dibalik meningkatnya penggunaan aplikasi zoom di masa pandemic covid 19 ini ada beberapa bahaya dalam penggunaan aplikasi tersebut diantaranya aplikasi ini kurang menerapkan sistem end-to-end encryption, fitur keamanan ini menjamin yang melihat konten adalah pengirim dan penerima saja. Selain itu, aplikasi ini disorot karena adanya celah keamanan dimana sebuah rapat online bisa disusupi orang yang tak diundang kemudian mengacau dengan menyebarkan ujaran kebencian dan bahasa kotor lainnya, tindakan ini disebut Zoombombing. (cnbcindonesia, 2020). 
Dalam proses perkuliahan online seorang tenaga pengajar pun harus mempersiapkan perkuliahan agar pesan yang akan disampaikan kepada mahasiswa dapat dipahami oleh mahasiswa. Persiapan dari materipun harus dipersiapkan agar kuliah online dapat berjalan dengan baik. Strategi belajar mengajar juga harus dapat diterapkan sehingga ada umpan balik dari dosen kepada mahasiswa atau dari mahasiswa ke dosen. Dalam proses perkuliahan online mahasiswa merespon strategi pembelajaran yang diterapkan oleh dosen dengan berbagia respon diantaranya hasil wawancara yang dilakukan bahwa menurut Harma bahwa strategi yang digunakan sudah bagus, menurut saya di situasi saat ini, kuliah online sangat membantu dalam penyampaian materi/pembelajaran yang disampaikan dosen kepada mahasiswa agar dapat dipahami, tanpa kuliah bertatap muka, kuliah dapat berjalan dengan semestinya, tetapi walau pembelajaran yang dilakukan melalui kuliah online dapat dilakukan dimana saja, akan tetapi banyak yang menjadi hambatan dalam perkuliahan online yang berlangsung terutama kuota data dan jaringan yang kadang-kadang loading/koneksi internet yang bermasalah. Menurut Candrawati mengungkapkan bahwa menurut saya strategi belajar mengajar yg diterapkan oleh Dosen dalam kuliah online sudah bagus tapi jangan terlalu keseringan kasih tugas, kasian mahasiswa/mahasiswi yang kurang bagus jaringannya di kampung masing-masing. Menurut Wa Ode Nofri Nelawati Yata bahwa strategi yang digunakan oleh dosen sudah cukup bagus dengan pemberian tugas membuat media lebih menambah kreativitas kami sebagai mahasiswa (Wawancara, 13 April 2020). Ketika ditanyakan kepada mahasiswa sejauhmana materi yang disampaikan melalui perkuliahan online dapat anda pahami oleh mahasiswa sebanyak 1 mahasiswa menjawab sangat dipahami, sebanyak 23 Mahasiswa menjawab dipahami, sebanyak 34 mahasiswa menjawab kadang-kadang dipahami dan sebanyak 4 mahasiswa menjawab tidak dipahami. Ini mengindikasikan bahwa perkuliahan online masih efektif di masa pandemi covid 19 ini, namun perlu kreativitas dari dosen untuk mengembangakan perkuliahan online. Lebih rinci dapat dilihat dari diagram berikut:

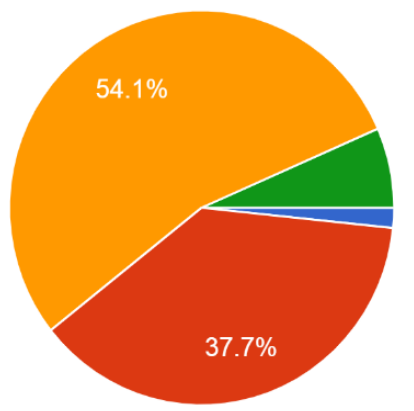

sangat dipaham

dipahami

Kadang-kadang dipahami

Tidak di pahami

\section{Gambar 5. Pemahaman mahasiswa terhadap materi perkuliahan}

Dalam metode pembelajaran baik perkuliahan tatap muka maupun perkuliahan online tentu ada faktor-faktor pendukung dan faktor penghambat dari suatu penerapan metode pembelajaran. Respon mahasiswa ketika ditanya faktor apa yang menjadi pendukung dalam proses perkuliahan online, mahasiswa memberikan respon seperti menurut Wa Ode meilin Saputri bahwa situasi di rumah/lokasi saya berada, jaringan internet yang cukup kuat, dan paket internet yang memadai, Selly Wati mengungkapkan yang menjadi pendukung saya adalah yang pertama orang tua saya, kedua paket selalu terisi dan yang ketiga adalah hp/laptop dan tidak lupa juga adalah jaringan apabila jaringan bagus itu sangat mendukung kuliah saya, menurut Suni Sundari mengungkapkan yang menjadi pendukung adalah keluarga memahami situasi 
kuliah online, paket internet yang selalu diutamakan dan jaringan yang memadai, sehingga kuliah online tetap bisa berjalan dengan lancar (wawancara, 13 April 2020). Sedangkan respon mahasiswa terhadap faktor penghambat dari kuliah online ini seperti yang diungkapkan oleh Siti Yuliani bahwa yang menjadi penghambat yaitu jaringan yang tidak stabil karena lokasi yang jauh dengan pemancar karna di kampung dan juga paket internet yang kadang cepat habis, Kadek mengungkapkan bahwa yang menjadi penghambat kadang orang tua kadang tidak mengerti kalau lagi kuliah online sampai sore, suka ngomel-ngomel karena dikira lagi main hp terus, padahal lagi kuliah online, menurut satria bahwa saat mati lampu karena jaringan juga padam dan saat kehabisan paket data karena di kampung jarang penjual paket dan pulsa (Wawancara, 13 April 2020). Pembelajaran online atau pembelajaran virtual dianggap sebagai paradigma baru dalam proses pembelajaran karena dapat dilakukan cara yang sangat mudah tanpa harus bertatap muka di suatu ruang kelas dan hanya mengandalkan sebuah aplikasi berbasis koneksi internet maka proses pembelajaran dapat berlangsung.Pembelajaran online adalah sebuah jenis proses pembelajaran yang mengandalkan koneksi internet untuk mengadakan proses pembelajaran. Menurut Fortune, Spielman, \& Pangelinan ada beberapa masalah yang dihadapi dalam pembelajaran online; materi ajar, interaksi belajar, dan lingkungan belajar. (Adijaya \& Santosa, 2018).

Di era globalisasi seperti sekarang ini dimana mobilitas dan aktivitas manusia sangat tinggi, koneksi internet menjadi hal yang sangat dibutuhkan dan sulit dipisahkan dalam kehidupan manusia untuk membantu berbagai macam kegiatan seperti dalam proses pembelajaran. Di era revolusi 4.0 manusia dituntun untuk mampu mengusai perkembangan ilmu pengetahuan dan teknologi. Namun dalam dunia pendidikan, khususnya dalam proses belajar mengajar terkadang belum menjadi sesuatu yang wajib menggantikan proses perkuliahan tatap muka dengan perkuliahan yang menggunakan aplikasi. Ini dapat dilihat dari respon mahasiswa terhadap pertanyaan lebih suka kuliah tatap muka atau kuliah online, maka seluruh mahasiswa menjawab memilih kuliah tatap muka, data dapat dilihat dari diagram di bawah ini:

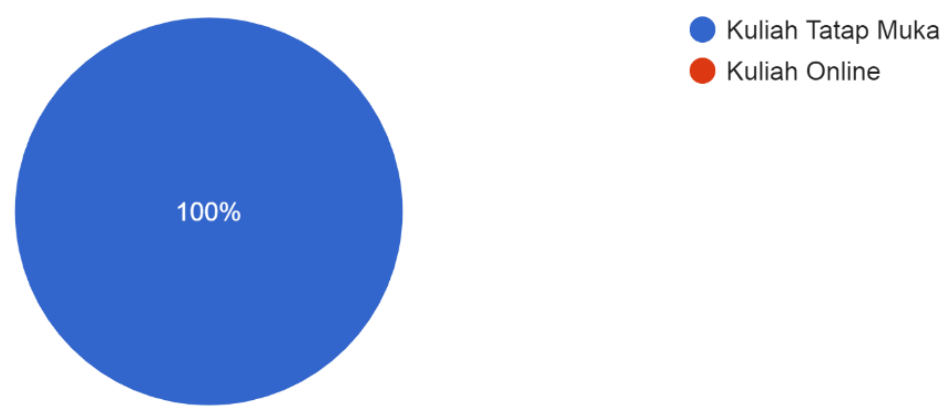

Gambar 6. Mahasiswa memilih kuliah tatap muka

Dari data diagram di atas terlihat bahwa mahasiswa secara keseluruhan memilih kuliah tatap muka. Ini mengindikasikan bahwa di era globalisasi interaksi antara mahasiswa dan dosen tidak bisa tergantikan oleh aplikasi. Respon mahasiswa yang memilih kuliah tatap muka dengan berbagai macam alasan, seperti hasil wawancara bahwa menurut Sulistia memilih kuliah tatap muka karena kalau kuliah tatap muka materinya cepat dimengerti dan berjalan dengan lancar dan tidak butuh data lagi meskipun tidak ada data kita msih bisa kuliah, menurut Nurul Magfirah bahwa kuliah online menjadi sangat berat untuk kami jalani, sebab beberapa tugas harus kami selesaikan secara tepat sehingga walau di rumah perasaan kami tertekan mengikuti perkuliahan online, sedangkan kalau tatap muka kita lebih familiar dengan diskusi santai sedikit 
tanya jawab dan memahami perkuliahan dengan baik, Menurut Meilin Saputri bahwa kuliah tatap muka lebih memahami materi karena dijelaskan secara langsung, banyak mempraktekkan sesuatu sehingga mudah dimengerti, dosen berusaha memberi kita pemahaman lewat contoh konkret, adanya diskusi, adanya evaluasi langsung untuk melihat sejauh mana kita mengerti, penilaian lebih valid dan obyektif, menurut Siti Yuliani bahwa kuliah tatap muka dilakukan di kampus dan juga kita bisa ketemu dengan teman-teman di kampus, cerita bersama teman dan juga bisa sharing sama teman, dan menurut Rini bahwa Karena kalau tatap muka itu dosennya bisa menjelaskan dengan baik serta bisa cepat dipahami (wawancara, 13 April 2020).

\section{SIMPULAN}

Temuan dalam penelitian ini adalah tempat yang biasa untuk kuliah dari 60 orang mahasiswa sebanyak 53 atau 88,3\% yang menjawab di rumah, sebanyak 2 orang mahasiswa atau $3,3 \%$ yang menjawab di kebun dan sebanyak 5 mahasiswa atau 8,3\% yang menjawab di rumah keluarga atau tetangga yang bagus jaringan internetnya. Mahasiswa menggunakan alat alektronik untuk mengikuti kuliah online adalah HP dan laptop. Aplikasi yang disuka dalam kuliah online, sebanyak 56 mahasiswa atau 91,8\% mahasiswa memilih aplikasi Whatsapp group, sebanyak 4 mahasiswa atau 6,5\% mahasiswa memilih aplikasi Zoom dan sebanyak 1 mahasiswa atau 1,6\% mahasiswa memilih aplikasi email sedangkan aplikasi yang tidak disuka dalam kuliah online, sebanyak 48 mahasiswa atau 80\% mahasiswa memilih aplikasi Zoom, sebanyak 11 mahasiswa atau 18,3\% mahasiswa memilih aplikasi email dan sebanyak 1 mahasiswa atau 1,7\% mahasiswa memilih aplikasi email Aplikasi Whatsapp group. Ketika ditanyakan kepada mahasiswa sejauhmana materi yang disampaikan melalui perkuliahan online dapat anda pahami oleh mahasiswa sebanyak 1 mahasiswa menjawab sangat dipahami, sebanyak 23 Mahasiswa menjawab dipahami, sebanyak 34 mahasiswa menjawab kadang-kadang dipahami dan sebanyak 4 mahasiswa menjadab tidak dipahami. Mahasiswa secara kesuluruhan atau 100\% memilih kuliah tatap muka dibandingkan dengan kuliah online. Persepsi mahasiswa terhadap kuliah online termasuk kategori tinggi, hal ini diharapkan dapat membantu mahasiswa dalam pelaksanaan proses perkuliahan di masa pandemi covid 19, karena perkuliahan yang baik dan benar akan membantu mahasiswa dalam meningkatkan pemahaman dan keilmuan mahasiswa. Meskipun masih banyak mahasiswa yang di daerahnya belum mendapatkan jaringan internet yang memadai tetapi tidak menjadi mengurangi semangat mahasiswa untuk mengikuti kuliah online. Mahasiswa menggunakan alat elektronik seperti HP dan laptop dalam mengikuti proses perkuliahan online. Bentuk-bentuk aplikasi yang digunakan dosen dalam perkuliahan online pada mahasiswa PIAUD semester IV adalah Whatsapp Group, Zoom, dan E-mail. Dalam proses perkuliahan online materi yang disampaikan oleh dosen tetap dapat dipahami oleh para mahasiswa. Faktor pendukung yang diperoleh mahasiswa dalam kuliah online diantaranya adalah ketersediaan paket data, HP, laptop dan jaringan internet yang mendukung. Faktor yang menjadi penghambat dalam proses perkuliahan online adalah kurangnya paket data dan internet. Mahasiswa lebih memilih perkuliahan dengan tatap muka dibandingkan dengan perkuliahan online karena interaksi antar dosen dan mahasiswa dapat dilakukan dalam ruangan kelas dan tidak membutuhkan aplikasi.

\section{REFERENSI}

Adijaya, N., \& Santosa, L. P. (2018). Persepsi Mahasiswa dalam Pembelajaran Online. Wanastra, 10(2), 105-110. 
Andika Prajana. (2017). Pemanfaatan Aplikasi Whatsapp Untuk Media Pembelajaran Dalam Lingkungan Uin Ar-Raniry Banda Aceh. Cyberspace: Jurnal Pendidikan Teknologi Informasi, 1(2), 122. https://doi.org/10.22373/cs.v1i2.1980

BPS Provinsi Sultra. (2019). banyaknya-desa-kelurahan-menurut-keberadaan-base-transceiverstation-bts-sinyal-telepon-seluler-dan-sinyal-internet-gsm-atau-cdma-2018. Retrieved from https://sultra.bps.go.id/statictable/2019/01/07/1372/banyaknya-desa-kelurahan-menurutkeberadaan-base-transceiver-station-bts-sinyal-telepon-seluler-dan-sinyal-internet-gsm-ataucdma-2018.html

cnbcindonesia. (2020). google-larang-karyawan-pakai-aplikasi-zoom-buat-rapat-online. Retrieved from https://www.cnbcindonesia.com/tech/20200409083234-37-150763/google-larangkaryawan-pakai-aplikasi-zoom-buat-rapat-online

Edi Firdaus. (2014). Analisis Perilaku Pengguna Sistem "Unikom Kuliah Online” Menggunakan Model Utaut. Majalah Ilmiah UNIKOM, 14(2), 297-310.

Febriadi, B., \& Nasution, N. (2017). Efisiensi sistem informasi berbasis online dalam pengumpulan rpkps mata kuliah Untuk pengembangan kompetensi program studi. Digital Zone: Jurnal Teknologi Informasi Dan Komunikasi, 8(1), 33-42. https://doi.org/10.31849/digitalzone.v8i1.621

Herayanti, L., Fuaddunnazmi, M., \& Habibi, H. (2017). Pengembangan Media Pembelajaran Berbasis Moodle pada Mata Kuliah Fisika Dasar. Jurnal Pendidikan Fisika Dan Teknologi, 1(3), 205. https://doi.org/10.29303/jpft.v1i3.260

Hermansyah, F. I. (2020). Pengambilan Kebijakan oleh Swedia dan Indonesia terhadap Pandemi Covid-19. Journal of Virology, 1-14.

IAIN Kendari. (2020). surat edaran rektor tindak lanjut kebijakan pencegahan. Retrieved from http://iainkendari.ac.id/content/detail/surat_edaran_rektor_tindak_lanjut_kebijakan_penc egahan

Indiati, I. (2008). Keefektifan strategi Pembelajaran Kooperatif dan Problem Posing dengan Kombinasi Tutorial Online untuk meningkatkan Pemahaman Materi Mata Kuliah Fisika Dasar. Pendidikan. Jurnal Media Penelitian, 2(2), 214-225.

Kemenag. (2020). Surat Edaran. $\quad$ Retrieved from https://adminku.kemenag.go.id/public/data/files/users/1/files/Surat Edaran 26-Mar2020 12-27-27.pdf

La Ode Anhusadar; Islamiyah. (2019). Kualifikasi Pendidik PAUD Sesuai Permendikbud Nomor. Journal on Early Childhood Education Research (JOECHER ), 1(2), 55-61. https://doi.org/10.37985/joecher.v1i2.8

Muzid, S., \& Munir, M. (2005). Persepsi Mahasiswa Dalam Penerapan e-Learning sebagai Aplikasi Peningkatan Kualitas Pendidikan (Studi Kasus Pada Universitas Islam Indonesia). Seminar Nasional Aplikasi Teknologi Informasi 2005 (SNATI 2005), 2005(Snati), 8.

Nailul Mona. (2020). KONSEP ISOLASI DALAM JARINGAN SOSIAL UNTUK MEMINIMALISASI EFEK CONTAGIOUS ( KASUS PENYEBARAN VIRUS CORONA DI INDONESIA ) Jumal Sosial Humaniora Terapan., 2(2), 117-125.

NEXTREN. (2020). 3-aplikasi-untuk-kuliah-online-selama-masa-karantina-virus-corona? Retrieved from https://nextren.grid.id/read/012065339/3-aplikasi-untuk-kuliah-onlineselama-masa-karantina-virus-corona?page $=$ all

Patria, L., \& Yulianto, K. (2011). Pemanfaatan Facebook Untuk Menunjang Kegiatan Belajar Mengajar Online Secara Mandiri.

Saputro, F. B., Somantri, M., \& Nugroho, A. (2017). Pengembangan Sistem Kuliah Online Universitas Diponegoro Untuk Antar Muka Mahasiswa Pada Perangkat Bergerak Berbasis Android. Pengembangan Sistem Kuliah Online Universitas Diponegoro Untuk Antar Muka Mahasiswa Pada Perangkat Bergerak Berbasis Android, 19(1), 15-21. https://doi.org/10.12777/transmisi.19.1.15-21

sevima. (2020). 5 kebijakan pendidikan masa darurat corona. Retrieved from 
https://sevima.com/5-kebijakan-pendidikan-masa-darurat-corona/

Sofiana, N. (2015). Implementasi Blended Learning Pada Mata Kuliah Extensive Listening. Nina Sofiana, 12(1), 2088-3102.

Solichin, A. (2009). Mengukur Tingkat Kenyamanan Penggunaan Sistem E-learning Moodle dalam Proses Knowledge Sharing: Studi Kasus di Universitas Budi Luhur. Budi Luhur Information Technology (BIT), 6(1), 43-50.

tekno.tempo.co. (2020). wabah-corona-bikin-unduhan-aplikasi-zoom-naik-1-270-persen/. Retrieved from https://tekno.tempo.co/read/1324176/wabah-corona-bikin-unduhanaplikasi-zoom-naik-1-270-persen $/$ full\&view $=$ ok

Yuberti. (2015). Online Group Discussion pada Mata Kuliah Teknologi Pembelajaran Fisika. Jurnal Ilmiah Pendidikan Fisika Al-Biruni, 4(2), 145. https://doi.org/10.24042/jpifalbiruni.v4i2.88

Yuliana, E., \& Winata, A. (2009). Persepsi mahasiswa terhadap tutorial online mata kuliah pengelolaan wilayah pesisir dan laut (Kasus: Program magister manajemen perikanan Universitas Terbuka). Jurnal Pendidikan Terbuka Dan Jarak Jauh, 10(2), 118-128. 